\title{
Implications of the progeny $x$ environment interaction in selection index involving characteristics of the common bean
}

\author{
L.K. Lima, M.A.P. Ramalho and A.F.B. Abreu \\ Departamento de Biologia, Universidade Federal de Lavras, Lavras, \\ MG, Brasil \\ Corresponding author: L.K. Lima \\ E-mail: lidianekely@yahoo.com.br
}

Genet. Mol. Res. 11 (4): 4093-4099 (2012)

Received March 13, 2012

Accepted June 4, 2012

Published September 19, 2012

DOI http://dx.doi.org/10.4238/2012.September.19.5

\begin{abstract}
Breeders normally select simultaneously for several traits in various environments. We investigated the effects of the progeny $x$ environment interaction on success in selection for several traits. The population used was obtained from a cross between the CVIII-85-11 line, which has a semi-erect to prostrate plant architecture and a cream with brown streaks bean type, and the BRS-Supremo cultivar, which has an erect plant architecture and black grains. In experiments conducted in the field, 47 progenies $\mathrm{F}_{4: 6}$ and $\mathrm{F}_{4: 7}$ were evaluated for two seasons for grain yield, plant architecture and grain type score. The variables were standardized and we obtained the sum of $\mathrm{Z}$. The components of genetic variance in the average of the two environments were nil due to the progeny $\mathrm{x}$ environment interaction, which would hinder successful simultaneous selection of characters.
\end{abstract}

Key words: Simultaneous selection; Progeny $\mathrm{x}$ environment interaction; Quantitative genetics; Genetic bean plant breeding; Genetic gain 


\section{INTRODUCTION}

When a new cultivar is recommended, it should present one or more attributes that are better than the pre-existing cultivars. For this reason, breeders need to observe several traits during the stages of the breeding program. In the case of the Carioca-type bean plant, in addition to grain yield and resistance to the main pathogens, the traits associated with grain type and plant architecture are being considered for the selection of lines that originate a new cultivar.

There are several alternative methods for the selection for several traits: tandem selection, in which selection is first made for one of the traits and later for the others in sequence; independent elimination levels, where a minimum acceptable level is established for each trait and the lines are chosen that reach this value for all the traits, and the selection index, which combines the multiple data sets obtained for the different traits in a single value (Falconer and Mackay, 1995; Bernardo, 2002). Several studies conducted on different species have shown that the selection index is the best option (Missio et al., 2004; Vieira et al., 2005). Costa et al. (2006) compared direct and indirect selection in segregated soybean populations and inferred that the greatest total gains were obtained with selection indexes that were distributed in all traits.

In addition, there are many alternatives to selection indexes in the literature (Cruz and Carneiro, 2006). The first, known as the classic index, was proposed for animal breeding by Smith in 1936 and by Hazel in 1943 and is therefore known as the Smith and Hazel Index (Bernardo, 2002). This methodology is restricted, because precise estimates need to be obtained for the genetic and phenotype variance and covariance and economic weights need to be established that are almost always subjective. Therefore, other options have been created that do not present the restrictions of the classic index. One of these methodologies that has been used in breeding programs in Brazil is the $\mathrm{Z}$ sum of the different traits, which is obtained by standardizing the variables (Mendes et al., 2009). This methodology is easy to apply and has an additional advantage of allowing graphic analysis that aids in the breeder's decision taking.

The progeny $\mathrm{x}$ environment interaction is very frequent in the bean plant crop (Faria et al., 2009; Mendes et al., 2009). However, there is no information regarding the potential effect of the progeny $\mathrm{x}$ environment interaction when considering several traits at the same time.

The objective of the present study was to quantify the effect of the progeny $\mathrm{x}$ environment interaction on the selection index involving grain yield, plant architecture score, and grain type.

\section{MATERIAL AND METHODS}

The experiments were carried out on the Experimental Farm of the Universidade Federal de Lavras (UFLA). Lavras is located at $21^{\circ} 14^{\prime}$ latitude South and $45^{\circ} 00^{\prime}$ longitude West, at an average altitude of $910 \mathrm{~m}$. A population was used from the cross between the CVIII-85-11 common bean line and the BRS-Supremo cultivar, identified in a diallel carried out by Mendes et al. (2009) as the most promising of 36 populations that were assessed. The CVIII-85-11 line from UFLA has semi-erect to prostrate plant architecture and a Carioca bean type, while the BRS-Supremo cultivar has an erect plant architecture and black grains and comes from the Empresa Brasileira de Pesquisa Agropecuária (Embrapa Arroz e Feijão).

The $F_{1}$ generation seeds were obtained by Mendes et al. (2009) in Lavras in 2007. The $\mathrm{F}_{2}$ to $\mathrm{F}_{4}$ generations were conducted in bulk. Ninety-eight plants were selected visually in the $\mathrm{F}_{4}$ generation, with more intense selection for Carioca-type grains and erect plant architecture 
that were multiplied in $\mathrm{F}_{4: 5}$. After a new selection, the 47 best progenies were assessed in the $\mathrm{F}_{4: 6}$ and $\mathrm{F}_{4: 7}$ generations, together with the parents.

The $\mathrm{F}_{4: 6}$ generation was assessed in the "dry" growing season and was sown in February 2009 , while the $\mathrm{F}_{4: 7}$ generation was assessed in the winter/spring growing season and sown in July 2009. A simple $7 \times 7$ lattice design was used, with plots of two 2-m rows spaced at 0.5 $\mathrm{m}$. Data for grain yield, plant architecture score, and grain type were obtained. The plant architecture was assessed using the modified score scale by Collicchio et al. (1997), where score 1 was attributed to the plots in which all the plants were prostrated and score 9 was given for completely erect plants. The grain type was also assessed by a scoring scale, ranging from 1 (below the commercial Carioca-type standard) to 5 (commercial standard).

The data for grain yield, plant architecture score, and grain type were first submitted to analysis of variance (ANOVA) by generation/environment. A joint analysis of the environments was then performed, considering the 49 treatments, 47 progenies, and the 2 parents, using the adjusted means.

Estimates of the genetic, phenotypic, and environmental correlations were obtained pairwise among the traits, using methodology similar to that presented by Vencovsky and Barriga (1992) and Bernardo (2002).

The index was obtained by the sum of the standardized variables (Mendes et al., 2009). In this case, the grain yield data, plant architecture score, and grain type of all the progenies were standardized for each replication to make them directly comparable. Thus, the $Z_{i j q}$ variable was calculated by the following estimator (Ramalho et al., 2005):

$$
Z_{i j q}=\frac{y_{i j q}-\bar{y}_{\cdot j q}}{s_{\cdot j q}}
$$

where $Z_{i j q}$ is the value of the standardized variable corresponding to progeny $i$ in replication $j$, referent to trait $q ; y_{i j q}$ is the observation of progeny $i$ in replication $j$, for trait $q ; \bar{y}_{j q}$ is the general mean of the trait $q$ in replication $j ; s_{j q}$ is the standard phenotype deviation of trait $q$ in replication $j$. As the Z-index can assume both negative and positive values, the value of 3 was added to make the values positive. In this case, the population mean, instead of 0 , assumed the value of 3. After standardizing the variables, the $Z_{i . q}$ sum was obtained per plot, constituting the $Z_{i}$ sum index of the standardized variables of the 3 traits.

The $Z_{i}$ index was submitted to ANOVA by environment/generations and joint analysis of all generations. In this case, ANOVA was performed while considering the randomized block design. The phenotype and genetic components were estimated by the 2 generations in the joint analysis.

\section{RESULTS}

The results of the joint ANOVA (data not shown) showed significant differences among environments, progenies, and the progeny $\mathrm{x}$ environment interaction for all of the traits. It should be noted that the environmental effect involves the effects of generations and sowing season. Regarding grain yield, the greatest mean was obtained in $\mathrm{F}_{4: 7}$ (Table 1). Although the differences were significant for the grain and plant architecture scores, they were not expressive and were always of a smaller magnitude in the $\mathrm{F}_{4: 7}$ generation (Table 1). 
Although the differences were significant for the grain and plant architecture scores, they were not expressive and were always of a smaller magnitude in the $\mathrm{F}_{4: 7}$ generation (Table 1).

Table 1. Means and estimates of the selective accuracies of the traits grain yield $(\mathrm{kg} / \mathrm{ha})$, plant architecture and grain type scores obtained in the assessment of bean plant progenies in two generations/growing seasons and the mean of the generations.

\begin{tabular}{|c|c|c|c|c|c|c|}
\hline & \multicolumn{2}{|c|}{$\mathrm{F}_{4: 6}$} & \multicolumn{2}{|c|}{$\mathrm{F}_{4: 7}$} & \multicolumn{2}{|c|}{ Mean of the generations } \\
\hline & Mean & Accuracy & Mean & Accuracy & Mean & Accuracy \\
\hline Grain yield & 2081 & 61.6 & 3494 & 83.8 & 2928 & 73.3 \\
\hline Plant architecture & 5.8 & 55.7 & 5.3 & 67.1 & 5.5 & 65.2 \\
\hline Grain type & 3.6 & 51.5 & 2.3 & 68.4 & 2.8 & 61.9 \\
\hline
\end{tabular}

The frequency distribution of the progeny means, considering the 2 environments, highlighted the difference between the progenies, which was detected in ANOVA for the 3 traits (Figure 1). The variation amplitude for grain yield was $65 \%$ of the value of the mean, $49 \%$ for plant architecture, and $62 \%$ for the grain type.
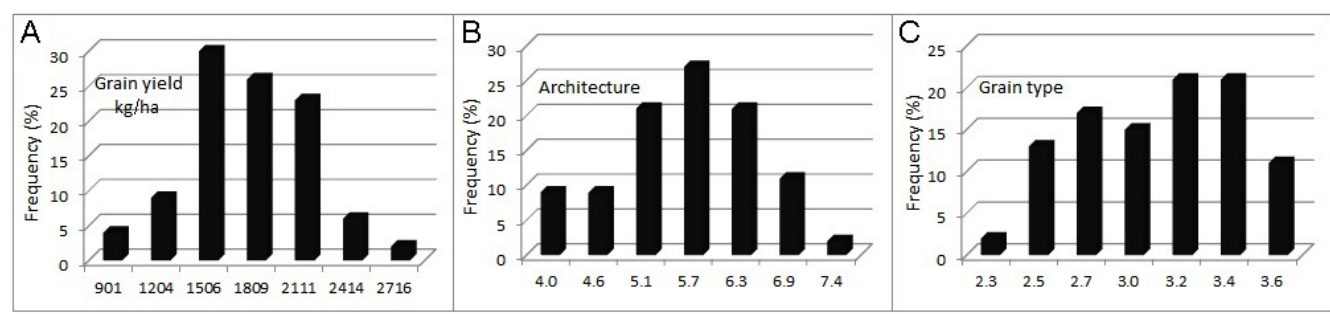

Figure 1. Frequency distribution of grain yield (A) plant architecture score (B) and grain type scores (C) in the mean of the 47 progenies in the $\mathrm{F}_{4: 6}$ and $\mathrm{F}_{4: 7}$ generations.

Table 2 shows the estimates of the genetic, phenotypic, and environmental correlations for the 3 traits. All of the estimates were of small magnitude for the 3 correlation types. However, the genetic correlation estimates between the grain yield and plant architecture were always negative.

Table 2. Estimates of genetic $\left(\mathrm{r}_{\mathrm{G}}\right)$ phenotype $\left(\mathrm{r}_{\mathrm{F}}\right)$ and environmental $\left(\mathrm{r}_{\mathrm{E}}\right)$ correlation among the traits plant architecture with grain yield and grain score, by generation/environment.

\begin{tabular}{lccccccc}
\hline & \multicolumn{3}{c}{ Grain yield } & & \multicolumn{3}{c}{ Grain score } \\
\cline { 2 - 4 } \cline { 6 - 8 } & $\mathrm{r}_{\mathrm{G}}$ & $\mathrm{r}_{\mathrm{F}}$ & $\mathrm{r}_{\mathrm{E}}$ & & $\mathrm{r}_{\mathrm{G}}$ & $\mathrm{r}_{\mathrm{F}}$ & $\mathrm{r}_{\mathrm{E}}$ \\
\hline $\mathrm{F}_{4: 6}$ (plant architecture) & -0.13 & -0.07 & 0.00 & & -0.11 & -0.05 & -0.08 \\
$\mathrm{~F}_{4: 7}$ (plant architecture) & -0.37 & -0.17 & 0.09 & & 0.06 & 0.08 & 0.10 \\
\hline
\end{tabular}

The sum of the standardized variables, the Z-index, is not only easy to obtain but it can also be estimated per plot and thus it enables ANOVA to be performed. This procedure was used especially to verify the possible influence of the progeny $\mathrm{x}$ generation (environ- 
ment) interaction in the index. There was significant difference among the progenies $(\mathrm{P} \leq$ $0.01)$ in ANOVA of the Z-index. Significance was also observed $(P \leq 0.01)$ for the progeny $\mathrm{x}$ environment interaction, indicating that the progeny performance did not coincide in the environments that were assessed. In the comparison of the sources of variation, the progeny $\mathrm{x}$ environment mean square was greater than the progeny mean square. The estimate of the correlation between the performance of the progeny means in the 2 environments was negative $\left(r_{G}=-0.39\right)$, showing that the progeny $x$ environment interaction was predominantly complex (Vencovsky and Barriga, 1992; Cruz and Carneiro, 2006), or rather, the coincidence in progeny ranking in the 2 environments was not high. This fact contributed to the heritability of the trait in the mean of the generations being nil (Table 3).

\begin{tabular}{l} 
Table 3. Summary of the joint analysis of variance of the progeny in the $\mathrm{F}_{4: 6}$ and $\mathrm{F}_{4: 7}$ generations, estimative of \\
genetic variance among progenies and progenies $\mathrm{x}$ environment interaction for the selection index obtained by \\
the sum of the standardized variables (Z-index). \\
\hline SV \\
\hline Progeny (P)
\end{tabular}

Another advantage of the Z-index is that it shows which traits are deficient in the progeny by graphic analysis (Figure 2). For example, the 2 progenies with the greatest Z-index (30 and 34) always presented values superior to the mean (dotted line in Figure 2) for all of the traits. A contrary fact occurred with the progeny with the lowest Z-index value, progeny 5 , which was deficient in the grain yield and grain type traits with values below the average population.

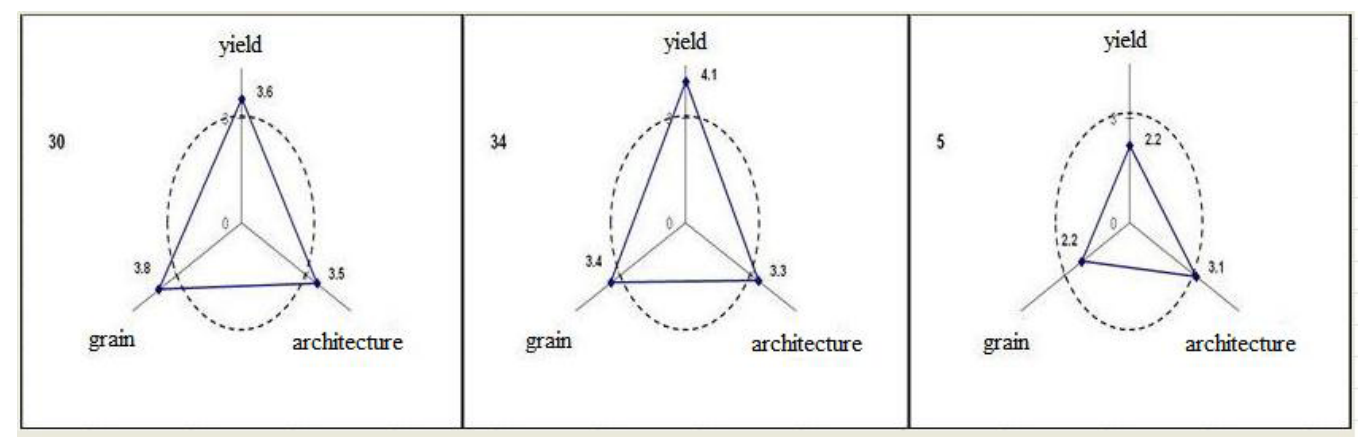

Figure 2. Graphic representation of the standardized values of grain yield, plant architecture and grain type of the progenies that presented the highest and lowest Z-index estimates.

\section{DISCUSSION}

The experimental precision with which progenies are assessed is an important aspect 
to be observed for successful selection. This is measured by the selective accuracy that reflects the correlation between the true genotypic value of the progeny and that predicted from the phenotypic data (Resende, 2002). The precision was moderate to high, accuracy greater than $50 \%$, which is a favorable condition for selection (Resende and Duarte, 2007).

The environmental conditions of the 2 sowing seasons were very different. In the dry growing season when the $\mathrm{F}_{4: 6}$ generation was assessed, the temperatures were high and there was only a little natural precipitation, thus the crop was irrigated for the full cycle. In the fall/ winter growing season that was sown in July when the $\mathrm{F}_{4: 7}$ generation was assessed, the temperatures were lower, especially at the start of the cycle and it rained only at the end of the experiment. Therefore, the variation observed among the generations should be attributed to the environmental effect. It is important to mention that if the environmental effect is disregarded, for grain yield for example, reduced yield would be expected in the $\mathrm{F}_{4: 7}$ generation compared to the $\mathrm{F}_{4: 6}$ generation, with the occurrence of dominance. However, dominance for bean plant grain yield is not very expressive (Moreto et al., 2007) and the reduction in the contribution of dominance from $\mathrm{F}_{4: 6}$ to $\mathrm{F}_{4: 7}$ was too small to be detected (Ramalho et al., 2012).

Reports in the literature of the association between plant architecture score and grain yield were also negative and of small magnitude (Silva et al., 2009), as observed in the present study. These estimates allowed to infer that it is possible to obtain erect plants without expressive yield reduction, as suggested by Collicchio et al. (1997) and Silva et al. (2009), and also that selection for Carioca-type beans can be made without any effect on plant architecture or grain yield.

Selection indexes in different species are frequently reported in the literature (Missio et al., 2004; Pedrozo et al., 2009). The Z-index has been used recently because it is easy to obtain, ANOVA can be carried out, and the values compared statistically since it is easy to interpret, especially using graphic analysis (Menezes Jr. et al., 2008; Mendes et al., 2009; Reis et al., 2011). In the present study, using the Z-index made it possible to verify the implication of the progeny $x$ environment interaction in the selection of more than 1 trait simultaneously. The effect of the interaction was very pronounced and the correlation of the Z-index in the 2 generations was negative. The occurrence of the progeny $x$ environment interaction in the common bean crop has been frequently reported in the literature for grain yield (Rocha et al., 2009; Faria et al., 2009) or plant architecture (Moreto et al., 2007; Menezes Jr. et al., 2008) alone. The simultaneous action of the 3 traits must have contributed to an increased effect of the progeny $\mathrm{x}$ environment interaction, a condition that does not favor the identification of progeny with superior performance for the 3 traits simultaneously in more than 1 environment.

\section{ACKNOWLEDGMENTS}

Research supported by the Foundation for Support to Research of the State of Minas Gerais (FAPEMIG) and Coordenação de Aperfeiçoamento de Pessoal de Nível Superior (CAPES) for the study grant.

\section{REFERENCES}

Bernardo R (2002). Breeding for Quantitative Traits in Plants. 1st edn. Stemma Press, Hardbound.

Collicchio E, Ramalho MAP and Abreu AFB (1997). Associação entre o porte da planta do feijoeiro e o tamanho dos grãos. Pesq. Agropec. Bras. 32: 297-304.

Costa MM, Mauro AOD, Unêda-Trevisoli SH, Arriel NHC et al. (2006). Modelos Biométricos Aplicados ao Melhoramento 
Genético. $2^{\mathrm{a}}$ ed. Universidade Federal de Viçosa, Viçosa.

Cruz CD and Carneiro PCS (2006). Modelos Biométricos Aplicados ao Melhoramento Genético. 2a ed. Universidade Federal de Viçosa, Viçosa.

Falconer DS and Mackay TFC (1995). Introduction to Quantitative Genetics. 4th edn. Longman, Essex.

Faria AP, Moda-Cirino V, Buratto JS, Silva CFB, et al. (2009). Interação genótipo x ambiente na produtividade de grãos de linhagens e cultivares de feijão. Acta Sci. Agron. 31: 579-585.

Mendes FF, Ramalho MAP and Abreu AFB (2009). Índice de seleção para escolha de populações segregantes de feijoeirocomum. Pesq. Agropec. Bras. 44: 1312-1318.

Menezes JAN Jr, Ramalho MAP and Abreu AFB (2008). Seleção recorrente para três caracteres do feijoeiro. Bragantia 67: 833-838.

Missio RF, Cambuim J, Moraes MLT and Paula RC (2004). Seleção simultânea de caracteres em progênies de Pinus caribaea Morelet var. bahamensis. Sci. For. 66: 161-168.

Moreto AL, Ramalho MAP, Nunes JAR and Abreu AFB (2007). Estimação dos componentes da variância fenotípica em feijoeiro utilizando o método genealógico. Ciênc. Agrotec. 31: 1035-1042.

Pedrozo CA, Benites FRG, Barbosa MHP and Resende MDV (2009). Eficiência de índice de seleção utilizando a metodologia REML/BLUP no melhoramento da cana-de-açúcar. Sci. Agraria 10: 31-36.

Ramalho MAP, Ferreira DF and Oliveira AC (2005). Experimentação em Genética e Melhoramento de Plantas. $2^{\mathrm{a}}$ ed. Universidade Federal de Lavras, Lavras.

Ramalho MAP, Santos JB, Abreu AFB and Nunes JAR (2012). Aplicações da Genética Quantitativa no Melhoramento de Plantas Autógamas. Universidade Federal de Lavras, Lavras.

Reis CAF, Gonçalves FMA, Ramalho MAP and Rosado AM (2011). Seleção de progênies de eucalipto pelo índice Z por MQM e BLUP. Pesq. Agropec. Bras. 46: 517-523.

Resende MDV (2002). Genética Biométrica e Estatística no Melhoramento de Plantas Perenes. EMBRAPA Informação Tecnológica, Brasília.

Resende MDV and Duarte JB (2007). Precisão e controle de qualidade em experimentos de avaliação de cultivares. Pesq. Agropec. Trop. 37: 182-194.

Rocha F, Toaldo D, Barili LD, Vale NM, et al. (2009). Efeito de ambiente sobre a produtividade de feijão carioca para o estado de Santa Catarina. Bragantia 68: 621-627.

Silva CA, Abreu AFB and Ramalho MAP (2009). Associação entre arquitetura de planta e produtividade de grãos em progênies de feijoeiro de porte ereto e prostrado. Pesq. Agropec. Bras. 44: 1647-1652.

Vencovsky R and Barriga P (1992). Genética Biométrica no Melhoramento. Sociedade Brasileira de Genética, Ribeirão Preto.

Vieira C, Borém A, Ramalho MAP and Carneiro JES (2005). Melhoramento do Feijão. In: Melhoramento de Espécies Cultivadas (Borém A, ed.). Universidade Federal de Viçosa, Viçosa, 301-392. 